\title{
Aplikasi Pemebelajaran Manasik Haji dan Umroh Berbasis Android
}

\author{
Dimas Robby Firmanda ${ }^{*}$, R. Rizal Isnanto, Ike Pertiwi Windasari \\ Program Studi Sistem Komputer, Fakultas Teknik, Universitas Diponegoro \\ Jl. Prof. Sudharto, SH, Kampus Undip Tembalang, Semarang, Indonesia 50275
}

\begin{abstract}
There are many moeslim people who do not know the information about how to do the pilgrimage and perform a pilgrimage to Mecca that usually called 'Hajj' and 'Umrah'. Hajj and Umrah are the duty for moslem who have ability to do that. In mobile application there are many advantages that can be used for learning, especially the app based Android. The purpose the research is to develop a mobile application as a learning media how to do Hajj and Umrah that is interactive for everyone through Android devices. With a guide app how to do Hajj and Umrah based Android, is expected can facilitate users to learn how to do Hajj and Umrah well and right. This application uses Android Studio software as IDE, in making the Android app. The first step to make the app is making a design like the design of the text, picture, animation, and audio about how to do Hajj and Umrah. Then, the second step is adding the basic rules of the pray in Arabic text with the meaning of that text. The third step is adding the picture, animation and audio about the pray and the proposition into Android Studio layout with Webview, and then doing initalization by adding the sound of every praying pronounciation in every Hajj and Umrah steps. The result of making the research is a multimedia application which display to user about the text, picture and audio about how to do Hajj and Umrah based Android and facilitate user to learn easier.
\end{abstract}

Keywords : application; Android; the rule of Hajj and Umrah; learning; animation; audio

\begin{abstract}
Abstrak-Dewasa ini sering kali kita jumpai banyak sekali dari masyarakat yang masih belum mengetahui informasi mengenai mengenai manasik haji dan umroh khususnya bagi umat islam yang merupakan salah satu rukun Islam yang wajib dilaksanakan bagi yang sudah mampu. Dalam aplikasi mobile banyak sekali yang dapat dimanfaatkan untuk pembelajaran diantaranya yaitu aplikasi berbasis Android. Dalam pembuatan Penelitian ini ditujukan untuk mengembangkan sebuah aplikasi mobile sebagai media pembelajaran manasik haji dan umroh yang bersifat interaktif bagi siapa saja melalui sebuah perangkat Android. Dengan adanya panduan manasik haji dan umroh berbasis Android diharapkan dapat memudahkan bagi pengguna untuk belajar mengenai tata cara manasik haji dan umroh dengan baik dan benar. Apikasi ini menggunakan perangkat lunak Android Studio sebagai IDE pembuatan aplikasi Android. Langkah pertama yang diperlukan dalam pembuatan Penelitian ini yaitu dengan membuat desain yang berupa teks, gambar, animasi, dan audio petunjuk dan tata cara haji dan umroh. Kemudian langkah kedua yaitu dengan memasukan doa yang disertai dasar-dasar hukumnya dalam bentuk tulisan Arab serta makna artinya. Langkah ketiga yaitu memasukkan gambar, animasi, dan audio yang telah dibuat beserta doa dan dalilnya kedalam
\end{abstract}

*) Penulis Korespondensi (Dimas Robby Firmanda) Email : abdurrobbi2304@gmail.com layout Android Studio yang dikemas ke dalam tampilan Webview kemudian untuk dilakukan inisialisasi dengan menambahkan suara dalam setiap pengucapan doa disetiap pelaksanaan rukun-rukun haji dan umroh. Hasil dari pembuatan aplikasi ini, adalah aplikasi multimedia yang menampilkan teks, gambar, animasi, dan audio untuk pembelajaran manasik haji dan umroh yang berbasis Android sehingga memudahkan bagi pengguna untuk mempelajarinya.

Kata Kunci: aplikasi; Android; Manasik haji dan umroh; pembelajaran; animasi; audio

\section{PENDAHULUAN}

Media merupakan sarana yang sangat digemari oleh masyarakat dalam melakuakan aktifitas salah satunya melalui teknologi komunikasi selular. Dalam penggunaan teknologi komunikasi selular masyarakat biasanya memanfaatkanya dalam berbagai hal, mulai dari komunikasi sms, telp, email, dan sebagainya. Dalam perkembangan terbaru sudah ada teknologi komunikasi selular berbasis mobile yang dapat dimanfaatkan bukan hanya sebagai media komunikasi namun bisa sebagai media pembelajaran. Dalam pembahasan kali ini akan membuat aplikasi yang dapat memudahkan masyarakat dalam mempelajari dan memahami tata cara rukun-rukun haji dan umroh yang baik dan benar. Dengan adanya penelitian ini diharapkan masyarakat khususya umat Islam akan lebih mudah dalam belajar dan memahami tata cara rukun-rukun haji dan umroh dengan baik dan benar. ${ }^{[1]}$.

Penelitian ini merujuk pada penelitian yang dilakukan oleh Dian Perdana Putra mahasiswa dari Universitas Muhammadiyah Surakarta. Peneliti membuat penelitian dengan judul "Aplikasi Alat Bantu Manasik Haji Berbasis" Android yang dipublikasikan pada 5 Maret 2014 yang lebih bertujuan sebagai petunjuk arah bagi jama'ah haji, sehingga ketika terjadi suatu kesalahan dimana jama'ah haji tersesat maka aplikasi ini bisa memperlihatkan lokasi dimana dia berada serta menunjukan arah tempat yang akan dituju karena terdapat menu peta online ${ }^{[2]}$.

Penelitian ini mencakup beberapa hal yang saling berhubungan diantaranya yaitu Multimedia adalah proses penggunaan komputer untuk menyajikan dan menggabungkan teks, suara, gambar, animasi, dan video dengan alat bantu (tool) dan berkomunikasi. multimedia juga diadopsi oleh dunia game.

Multimedia dimanfaatkan juga dalam dunia pendidikan dan bisnis. Di dunia pendidikan, 
multimedia digunakan sebagai sarana media pengajaran, baik dalam kelas maupun secara sendirisendiri. Di dunia bisnis, multimedia digunakan sebagai media profil perusahaan, profil produk bahkan sebagai media kios informasi dan pelatihan dalam sistem e-learning ${ }^{[3]}$, manasik haji.

Dalam melaksanakan Ibadah Haji juga harus memenuhi syarat wajib dan sahnya ibadah Haji. Syarat wijib dan sahnya Ibadah Haji adalah Islam, berakal, baligh (sudah memenuhi batas usia diperbolehkanya melaksanakan ibadah Haji), merdeka, mampu (kemampuan harta, kesehatan jasmani, perjalanan yang aman, bagi wanita harus disertai mahrom, dan tidak dalam masa 'iddah) khusus bagi wanita harus disertai mahrom (saudara sekandung) baginya ketika menunaikan ibadah Haji $^{[4]}$, haji tamatu' adalah berihram untuk umrah di bulan-bulan haji dan umroh setelah itu berihram untuk haji dan umroh pada tahun itu juga ${ }^{[5]}$, urutan proses ibadah Haji yang dimulai dari tanggal 8 Dzulhijah (Hari Tarwiyah) sampai tanggal 12 Dzulhijah (bagi yang mengambil nafar awal) atau 13 Dzulhijah (bagi yang mengambil nafar tsani) ${ }^{[6]}$, manasik umroh yaitu tata cara pelaksanaanya haruslah sesuai dengan tuntunan Rosulullah Sholallahu'alaiwasallam yaitu harus terpnuhinya rukun dan wajib umroh yang sesuai dengan petunjuk Rosulullah Sholallahu'alaiwasallam dan diantara rukun dan wajib dalam melaksanakan ibadah umroh yang sesuai dengan tuntunan Rosulullah Sholallahu'alaiwasallam adalah sebagai berikut:

1) Rukun umrah:

Ihram (niat masuk atau memulai untuk beribadah), thowaf, sa'i, tahallul.

2) Wajib umroh

Ihram dari miqat, dan mencukur (gundul) rambut atau memendekkannya ${ }^{[7]}$, sama halnya dengan pelaksanaan ibadah haji, Ibadah Umroh juga harus memenuhi syarat wajib dan sahnya ibadah Haji. Syarat wijib dan sahnya Ibadah Haji adalah Islam, berakal, baligh (sudah memenuhi batas usia diperbolehkanya melaksanakan ibadah Umroh), merdeka, mampu (kemampuan harta, kesehatan jasmani, perjalanan yang aman, bagi wanita harus disertai mahrom, dan tidak dalam masa 'iddah), khusus bagi wanita harus disertai mahrom (saudara sekandung) baginya ketika menunaikan ibadah $\mathrm{Umroh}^{[8]}$, Android merupakan sistem operasi berbasis linux yang bersifat terbuka (open source) dan dirancang untuk perangkat selular layar sentuh seperti smartphone dan tablet. Android dikembangkan oleh Android, Inc., dengan dukungan finansial dari google yang kemudian dibelinya pada tahun 2005. Android dirilis secara resmi pada Thun 2007 bersamaan dengan didirikanya Open Handset Alliance ${ }^{[9]}$.

Dalam penelitian ini menggunakan perangkat lunak Android Studio, yaitu IDE (integrated development environment) resmi untuk pengembangan aplikasi Android, berbasis
IntelliJIDEA. Dukungan built-in untuk Google Cloud Platform, sehingga memudahkan untuk mengintergrasikan Google Cloud Messaging dan App Engine[10].

\section{METODE PENELITIAN}

Bagian bab ini membahas mengenai kebutuhan dan metode yang digunakan untuk pengembangan sistem.Terdapat 5 tahapan yaitu analisa kebutuhan, desain sistem, tahap programming, implementasi dan pengujian.

Tahap pertama adalah analisa kebutuhan. Kebutuhan sistem meliputi tahap analisa kebutuhan sistem. Kebutuhan sistem meliputi kebutuhan akan perangkat lunak dan perangkat keras. Perangkat lunak yang digunakan adalah Android Studio. Sedangkan perangkat keras yang digunakan adalah laptop ASUS A43S dengan RAM 2 GB dan smartphone Xiaomi Redmi 3S dengan RAM 2 GB dan sistem operasi android marshmallow.

Tahap kedua adalah desain sistem dan antarmuka. Pada tahap ini dibuatlah desain antarmuka yang dapat dengan mudah dipahami dan dijalankan oleh pengguna yang memang diperuntukan untuk orang yang sudah memenuhi usia untuk melaksanakan ibadah haji terutama orang tua.

Tahap ketiga adalah tahap pemrograman. Tahap ini merupakan tahap pengcodingan program agar desain yang sudah dirancang dapat dijalankan sesuai harapan, yaitu dengan menggunakan perangkat Lunak Android Studio.

Tahap keempat adalah tahap implemntasi dan pengujian. Dalam tahap ini penelitian yang telah dibuat akan diujikan hasilnya. Yaitu dengan mengujikan ke beberapa smartphone dan juga dengan memberikan pertanyaan kepada pengguna tentang kemudahan, tampilan dan manfaat aplikasi Manasik Haji dan Umroh pada penelitian ini.

\section{PERANCANGAN SISTEM}

\section{A. Analisis Kebutuhan Fungsional}

Kebutuhan fungsional adalah layanan sistem yang berisikan proses-proses yang dibutuhkan oleh sistem. Kebutuhan fungsional dari rancangan aplikasi yang akan dibuat ini adalah:

1. Di dalam menu panduan haji terdapat beberapa fasilitas seperti dalil/ hukum dasar diperintahkanya ibadah haji, sunnah-sunnah serta larangan-larangan dalam ibadah haji, dan juga tata cara ibadah haji tamattu' yang benar sesuai dengan syari'at Islam.

2. Terdapat fasilitas dalil/ hukum dasar diperintahkanya ibadah haji, sunnah-sunnah serta larangan-larangan dalam ibadah umroh, dan juga tata cara ibadah umroh di dalam menu panduan umroh.

3. Adanya fasilitas doa-doa dalam melakukan ibadah haji dan umroh. 
4. Dilengkapi fasilitas audio sebagai penunjang dalam memahami dan menghafal doa-doa di dalam ibadah haji dan umroh.

\section{B. Analisis Kebutuhan non-Fungsional}

Kebutuhan non-fungsional merupakan kebutuhan yang tidak berhubungan langsung dengan spesifik yang telah dirancang oleh sistem. Batasan ini mengenai kemampuan aplikasi di luar fungsi utama. Kebutuhan non-fungsional pada aplikasi yang dibuat yaitu berjalan di Android minimal versi Jelly Bean, aplikasi berjalan tanpa akses internet.

\section{Desain}

Perancangan konseptual meliputi desain proses dari sistem. Desain proses dibuat berdasarkan kebutuhan fungsional dan kebutuhan data. Aliran Sistem digambarkan dengan menggunakan UML (Unified Modelling Language).

\section{Use Case Diagram}

Use case diagram menggambarkan fungsionalitas yang diharapkan dari sebuah sistem. Sebuah use case merepresentasikan sebuah interaksi antara aktor dengan sistem. Komponen utama use case diagram ini adalah aktor dan use case. Pada pembuatan aplikasi pembelajaran manasik haji dan umroh ini adalah user (pengguna) yang bertindak sebagai aktor yang menjalankan sistem.

Use case diagram pada rancangan aplikasi ini ditunjukan pada gambar 1 .

\section{Sequence Diagram}

Sequence Diagram menggambarkan fungsionalitas dari masing-masing use case dan interaksi yang terjadi antar objek dalam sistem. Terdapat 20 use case pada diagram use case, sehingga penggambaran diagram sequence juga mengikuti jumlah use case dalam diagram use case.

1. Sequence Diagram Memilih Menu Panduan Haji

Sequence diagram menu Panduan Haji ditunjukan oleh Gambar 2.

2. Sequence Diagram Memilih Menu Tata Cara Haji Tamattu'

Sequence diagram memilih Tata Cara Haji Tamattu' yang dipilih ditunjukan oleh Gambar 3 .

3. Sequence Diagram Panduan Rukun dan Wajib Umroh

Sequence diagram melihat menu panduan rukun dan wajib umroh yang dipilih ditunjukan oleh Gambar 4.

4. Sequence Diagram Panduan Rukun dan Wajib Haji

Sequence diagram melihat menu panduan rukun dan wajib haji yang dipilih ditunjukan oleh Gambar 5.
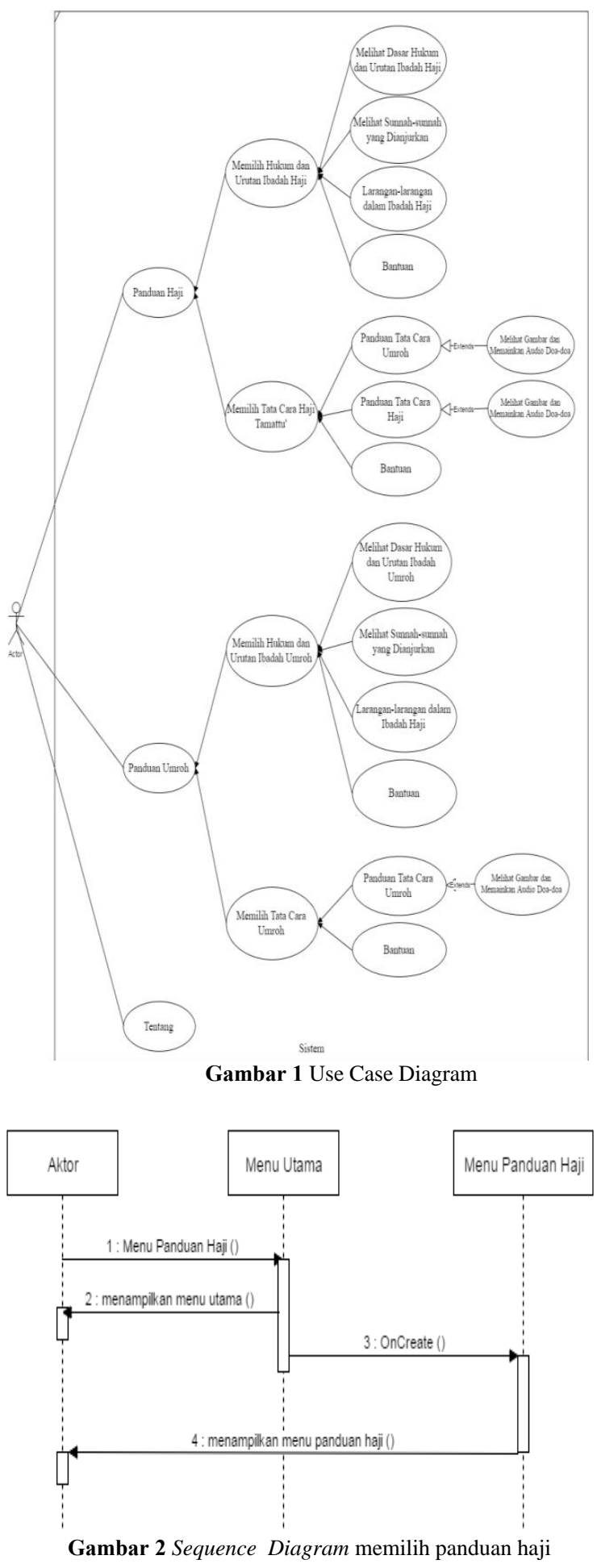


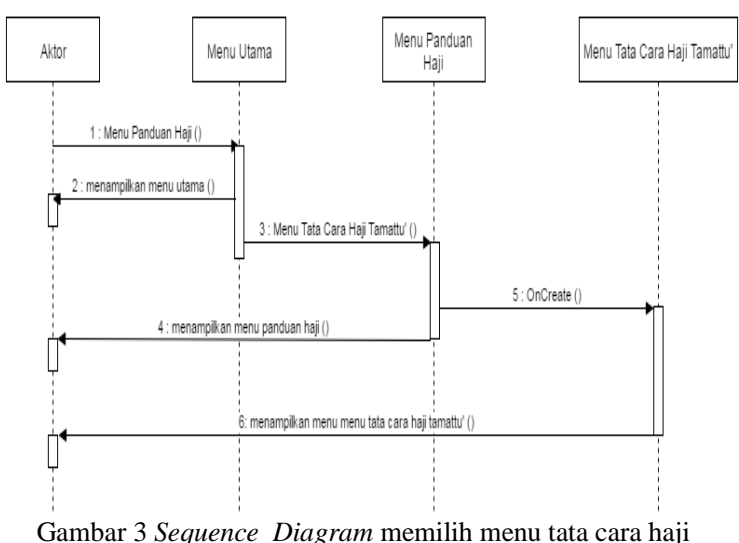

Gambar 3 Sequence Diagram memilih menu tata cara haji tamattu'
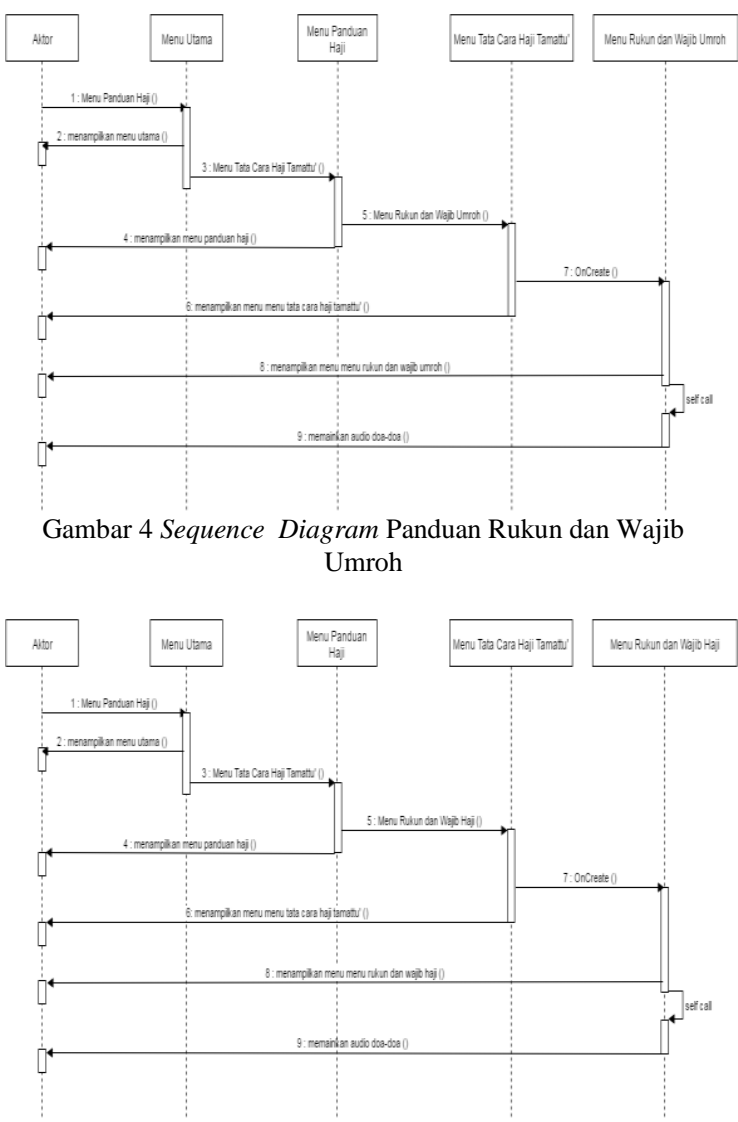

Gambar 5 Sequence Diagram Panduan Rukun dan Wajib Haji

\section{Diagram Kelas}

Diagram Kelas dari aplikasi dibuat pada Penelitian ini ditunjukkan pada Gambar 6.

\section{IMPLEMENTASI DAN PENGUJIAN}

\section{A. Implementasi}

Implementasi antarmuka merupakan penerapan dari rancangan antarmuka Aplikasi Panduan Manasik Haji dan Umroh.

Berikut tampilan antarmuka hasil implementasi dari rancangan antar muka aplikasi Panduan Manasik Haji dan Umroh menggunakan Android Studio.

1. Tampilan Menu Utama

Tampilan menu Utama dapat dilihat pada gambar 7.
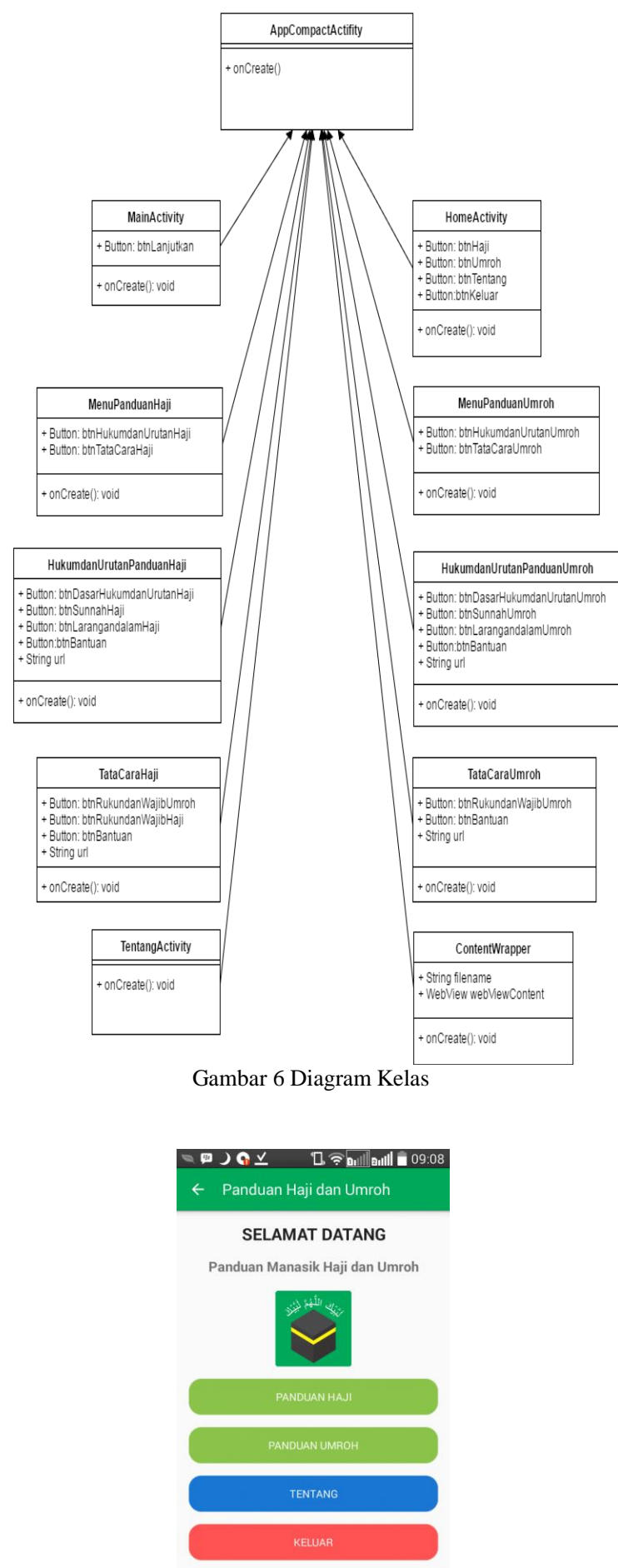

Gambar 7 Tampilan Menu Utama

2. Tampilan menu Tata Cara Haji Tamattu' Tampilan menu Tata Cara Haji Tamattu' dapat dilihat pada Gambar 8. 


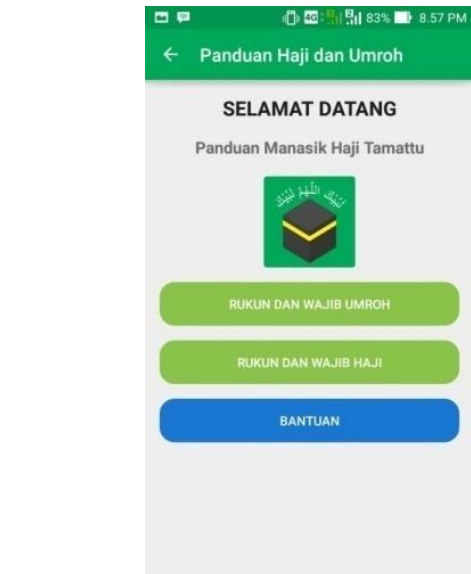

Gambar 8 Tampilan Halaman Tata Cara Haji Tamattu'

3. Tampilan Halaman Rukun dan Wajib Umroh (di dalam Haji Tamattu')

Tampilan halaman Rukun dan wajib Umroh dapat dilihat pada gambar 9 .

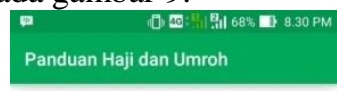

Tata Cara Umroh (di dalam haji tamattu')

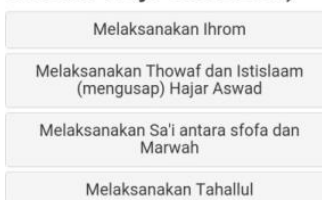

Gambar 9 Tampilan Halaman Rukun dan Wajib Umroh

4. Tampilan Halaman Rukun dan Wajib Haji

Tampilan halaman Rukun dan wajib Haji dapat dilihat pada gambar 10.

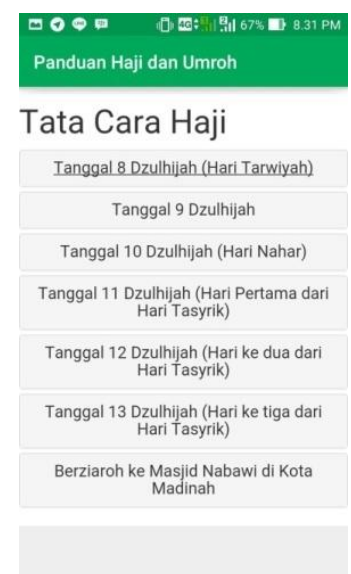

Gambar 10 Tampilan Halaman Rukun dan Wajib Haji

\section{B. Rencana Pengujian}

Pada Penelitian ini tahap pengujian yang dilakukan adalah metode black-box yaitu menguji fungsionalitas dari perangkat lunak saja tanpa harus mengetahui struktur internal program (source code) dan juga pengujian langsung kepada responden bagaimana pendapat mereka tentang kemudahan aplikasi, tampilan layout aplikasi dan manfaat dari aplikasi.

\section{Hasil Pengujian}

1. Pengujian Menu Utama

Hasil pengujian menu Utama dapat dilihat pada

Tabel 1.

Tabel 1 Pengujian Menu Utama

\section{Detail dan Hasil Pengujian}

\begin{tabular}{cl}
\hline Masukan & $\begin{array}{l}\text { Pengguna membuka aplikasi } \\
\text { manasik haji dan umroh } \\
\text { kemudian tekan tombol } \\
\text { lanjutkan pada menu intro. }\end{array}$ \\
Hasil yang & Tampil halaman menu \\
diharapkan & Utama dengan beberapa \\
& menu didalamnya yaitu: \\
& Panduan Haji, Panduan \\
& Umroh, Tentang, dan \\
& Keluar. \\
& $\begin{array}{l}\text { Sistem menampilkan } \\
\text { halaman menu Utama } \\
\text { dengan beberapa menu } \\
\text { didalamnya yaitu: Panduan }\end{array}$ \\
& Haji, Panduan Umroh, \\
& Tentang, dan Keluar. \\
Hasil Pengujian & \multicolumn{2}{c}{ Berhasil } \\
\hline
\end{tabular}

2. Pengujian Menu Panduan Haji

Hasil pengujian menu Panduan Haji dapat dilihat pada Tabel 2.

Tabel 2 Pengujian Menu Panduan Haji

\begin{tabular}{cl}
\hline \multicolumn{3}{c}{ Detail dan Hasil Pengujian } \\
\hline Masukan & $\begin{array}{l}\text { Pengguna memilih/ } \\
\text { mengklik menu Panduan }\end{array}$ \\
& Haji pada menu Utama \\
& Tampil halaman menu \\
Hasil yang & Panduan Haji dengan \\
diharapkan & beberapa menu didalamnya \\
& yaitu: Hukum dan Urutan \\
& Ibadah Haji, dan Tata \\
& Cara Haji Tamattu' \\
& Sistem menampilkan \\
& halaman menu Panduan \\
& Haji dengan beberapa menu \\
Pengamatan & didalamnya yaitu: Hukum \\
& dan Urutan Ibadah Haji, \\
& dan Tata Cara Haji \\
& Tamattu'.
\end{tabular}

Hasil Pengujian
Berhasil 
3. Pengujian Menu Tata Cara Haji Tamattu'

Hasil pengujian menu Tata Cara Haji

Tamattu' dapat dilihat pada Tabel 3.

Tabel 3 Pengujian Menu Tata Cara Haji Tamattu'

\section{Detail dan Hasil Pengujian}

$\begin{array}{ll}\text { Masukan } & \begin{array}{l}\text { Pengguna memilih/ } \\ \text { mengklik menu Tata Cara } \\ \text { Haji Tamattu' pada menu } \\ \text { Panduan Haji. }\end{array} \\ \text { Hasil yang } & \text { Tampil halaman menu Tata } \\ \text { diharapkan } & \text { Cara Haji Tamattu' dengan } \\ & \text { beberapa menu didalamnya } \\ & \text { yaitu: Panduan Rukun dan } \\ & \text { Wajib Umroh di dalam } \\ & \text { Ibadah Haji, Panduan } \\ & \text { Rukun dan Wajib Haji, dan } \\ & \text { Bantuan. } \\ \text { Pengamatan } & \text { Sistem menampilkan } \\ & \text { halaman menu Tata Cara } \\ & \text { Haji Tamattu' dengan } \\ & \text { beberapa menu didalamnya } \\ & \text { yaitu: Panduan Rukun dan } \\ & \text { Wajib Umroh di dalam } \\ & \text { Ibadah Haji, Panduan } \\ & \text { Rukun dan Wajib Haji, dan } \\ & \text { Bantuan. }\end{array}$

Hasil Pengujian Berhasil

4. Pengujian Panduan Rukun dan Wajib Umroh (Umroh yan ada di dalam Haji Tamattu')

Hasil pengujian halaman Panduan Rukun dan

Wajib Umroh dapat dilihat pada Tabel 4.

Tabel 4 Pengujian Menu Panduan Rukun dan Wajib Umroh (Umroh yan ada di dalam Haji Tamattu')

\section{Detail dan Hasil Pengujian}

\begin{tabular}{|c|c|}
\hline Masukan & $\begin{array}{lr}\text { Pengguna } & \text { memilih/ } \\
\text { mengklik menu Panduan } \\
\text { Rukun dan Wajib Umroh } \\
\text { pada menu Tata Cara Haji. }\end{array}$ \\
\hline $\begin{array}{l}\text { Hasil yang } \\
\text { diharapkan }\end{array}$ & $\begin{array}{l}\text { Tampil halaman Panduan } \\
\text { Rukun dan Wajib Umroh } \\
\text { berisi tentang penjelasan } \\
\text { mengenai Tata Cara Rukun } \\
\text { dan Wajib Umroh secara } \\
\text { berurutan. }\end{array}$ \\
\hline Pengamatan & $\begin{array}{l}\text { Sistem menampilkan } \\
\text { halaman menu Panduan } \\
\text { Rukun dan Wajib Umroh } \\
\text { berisi tentang penjelasan } \\
\text { mengenai Tata Cara Rukun } \\
\text { dan Wajib Umroh secara } \\
\text { berurutan. }\end{array}$ \\
\hline Hasil Pengujian & Berhasil \\
\hline
\end{tabular}

5. Pengujian Panduan Rukun dan Wajib Haji

Hasil pengujian halaman Panduan Rukun dan

Wajib Haji dapat dilihat pada Tabel 5.

Tabel 5 Pengujian Menu Panduan Rukun dan Wajib Haji

\section{Detail dan Hasil Pengujian}

\begin{tabular}{|c|c|}
\hline Masukan & $\begin{array}{l}\text { Pengguna } r \text { memilih/ } \\
\text { mengklik menu Panduan } \\
\text { Rukun dan Wajib Haji } \\
\text { pada menu Tata Cara } \\
\text { Haji. }\end{array}$ \\
\hline $\begin{array}{l}\text { Hasil yang } \\
\text { diharapkan }\end{array}$ & $\begin{array}{l}\text { Tampil halaman Panduan } \\
\text { Rukun dan Wajib Haji } \\
\text { berisi tentang penjelasan } \\
\text { mengenai Tata Cara Rukun } \\
\text { dan Wajib Haji secara } \\
\text { berurutan. }\end{array}$ \\
\hline Pengamatan & $\begin{array}{l}\text { Sistem menampilkan } \\
\text { halaman menu Panduan } \\
\text { Rukun dan Wajib Haji } \\
\text { berisi tentang penjelasan } \\
\text { mengenai Tata Cara Rukun } \\
\text { dan Wajib Haji secara } \\
\text { berurutan. }\end{array}$ \\
\hline Hasil Pengujian & Berhasil \\
\hline
\end{tabular}

\section{Pengujian Pada Ponsel Cerdas Android}

Aplikasi Panduan Manasik Haji dan Umroh ini sudah diuji pada beberapa versi Android. Daftar ponsel cerdas yang digunakan untuk menguji aplikasi ini dapat dilihat pada Tabel 6.

Tabel 6 Daftar ponsel cerdas Android untuk pengujian aplikasi

\begin{tabular}{cccc}
\hline No & Jenis & OS & $\begin{array}{c}\text { Keteran } \\
\text { gan }\end{array}$ \\
\hline 1 & $\begin{array}{c}\text { Xiom Redmi } \\
\text { Note 3 } \\
\text { Samsung } \\
2\end{array}$ & Lollipop & Ok \\
Galaxy Note 3 & Kitkat & Ok \\
3 & $\begin{array}{c}\text { SC } \\
\text { Asus Zenfone } \\
2\end{array}$ & Lollipop & Ok \\
4 & $\begin{array}{c}\text { Infinix x510 } \\
\text { Andromax }\end{array}$ & Marshmellow & Ok \\
5 & $\begin{array}{c}\text { C46B2H V5.4 } \\
\text { Samsung }\end{array}$ & Lollipop & Ok \\
6 & $\begin{array}{c}\text { Galaxy Core 2 } \\
\text { Asus Zenfone } \\
\text { Laser }\end{array}$ & Lollipop & Ok \\
\hline
\end{tabular}

\section{E. Pengujian Pengguna}

Pengujian oleh pengguna pada aplikasi Panduan Manasik Haji dan Umroh dilakukan dengan mengambil pendapat dari 7 pengguna untuk menjalankan aplikasi Panduan Manasik Haji dan Umroh. Hasil pengujianya dapat dilihat pada table 7 . 
Tabel 7 Hasil Pengujian Pengguna

\begin{tabular}{|c|c|c|}
\hline Pertanyaan & $\begin{array}{l}\text { Kriteria } \\
\text { Jawaban }\end{array}$ & $\begin{array}{c}\text { Jumlah } \\
\text { Tanggapan } \\
\text { Pengguna }\end{array}$ \\
\hline \multirow{4}{*}{$\begin{array}{l}\text { Pendapat/tanggapan } \\
\text { pengguna mengenai } \\
\text { pengaturan kontrol } \\
\text { pada Aplikasi } \\
\text { Pembelajaran } \\
\text { Manasik Haji dan } \\
\text { Umroh (kemudahan } \\
\text { pengguna dalam } \\
\text { menjalankan } \\
\text { aplikasi). }\end{array}$} & $\begin{array}{l}\text { Sangat } \\
\text { Mudah }\end{array}$ & 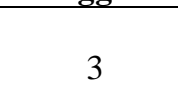 \\
\hline & $\begin{array}{l}\text { Mudah } \\
\text { Cukup }\end{array}$ & 4 \\
\hline & Mudah & - \\
\hline & $\begin{array}{l}\text { Kurang } \\
\text { Mudah } \\
\text { Tidak } \\
\text { Mudah }\end{array}$ & - \\
\hline \multirow{5}{*}{$\begin{array}{l}\text { Pendapat/tanggapan } \\
\text { pengguna mengenai } \\
\text { tampilan obyek dan } \\
\text { desain dari Aplikasi } \\
\text { Pembelajaran } \\
\text { Manasik Haji dan } \\
\text { Umroh. }\end{array}$} & $\begin{array}{l}\text { Sangat } \\
\text { Menarik }\end{array}$ & 1 \\
\hline & Menarik & 2 \\
\hline & $\begin{array}{l}\text { Cukup } \\
\text { Menarik }\end{array}$ & 4 \\
\hline & $\begin{array}{l}\text { Kurang } \\
\text { Menarik }\end{array}$ & - \\
\hline & $\begin{array}{l}\text { Tidak } \\
\text { Menarik }\end{array}$ & - \\
\hline
\end{tabular}

Tabel 7 Hasil Pengujian Pengguna (lanjutan)

\begin{tabular}{|c|c|c|}
\hline Pertanyaan & $\begin{array}{l}\text { Kriteria } \\
\text { Jawaban }\end{array}$ & $\begin{array}{c}\text { Jumlah } \\
\text { Tanggapan } \\
\text { Pengguna } \\
\end{array}$ \\
\hline $\begin{array}{l}\text { Pendapat/tanggapan } \\
\text { pengguna mengenai } \\
\text { manfaat yang } \\
\text { diberikan dari } \\
\text { Aplikasi } \\
\text { Pembelajaran } \\
\text { Manasik Haji dan } \\
\text { Umroh. }\end{array}$ & $\begin{array}{l}\text { Sangat } \\
\text { Bermaanfaat } \\
\text { Bermaanfaat } \\
\text { Cukup } \\
\text { Bermaanfaat } \\
\text { Kurang } \\
\text { Bermaanfaat } \\
\text { Tidak } \\
\text { Bermaanfaat }\end{array}$ & 4 \\
\hline
\end{tabular}

Dari hasil pengujian yang dilakukan melalui kuisioner yang diberikan kepada beberapa pengguna didapatkan,

1. Pengaturan kontrol pada Aplikasi Pembelajaran Manasik Haji dan Umroh cukup sederhana dan mudah dipahami, sehingga memudahkan pengguna dalam menjalankanya.

2. Tampilan obyek dan desain yang dibuat pada Aplikasi Pembelajaran Manasik Haji dan Umroh cukup sederhana, sehingga cukup menarik dan mudah dipahami oleh pengguna.
3. Dari Hasil survei ini didapatkan bahwa Aplikasi Pembelajaran Manasik Haji dan Umroh sangatlah bermanfaat bagi masyarakat khususnya kaum muslimin di Indonesia yang akan melaksanakan baik ibadah haji maupun umroh.

\section{PENUTUP}

Dari hasil pengujian dan analisis Aplikasi Pembelajaran Manasik Haji dan Umroh Menggunakan Android Studio dapat disimpulkan halhal yaitu telah dikembangkan sebuah aplikasi multimedia yang mencakup teks, gambar, animasi, dan audio sebagai Aplikasi Pembelajaran Manasik Haji dan Umroh. Aplikasi Pembelajaran Manasik Haji dan Umroh dibuat menggunakan aplikasi Android Studio dengan tampilan menu menggunakan html. Menurut koresponden Tampilan pada Aplikasi Pembelajaran Manasik Haji dan Umroh dari tujuh pendapat paling banyak memilih mudah dijalakan dan dipahami oleh pengguna ponsel cerdas Android. Menurut koresponden tampilan pada Aplikasi Pembelajaran Manasik Haji dan Umroh dari tujuh pendapat paling banyak memilih cukup menarik dalam menampilkan menu-menu pada tampilan layout yang sederhana namun mudah dipahami. Menurut koresponden Aplikasi Pembelajaran Manasik Haji dan Umroh dari tujuh pendapat paling banyak memilih sangat bermanfaat untuk media pembelajaran manasik haji dan umroh terutama untuk jama'ah haji di Indonesia yang melaksanakan haji tamattu'. Tombol-tombol dan fungsi-fungsi yang terdapat pada aplikasi dapat berfungsi dengan baik dan sesuai dengan fungsionalitasnya masing-masing.

Berdasarkan hasil pengujian Aplikasi Pembelajaran Manasik Haji dan Umroh Menggunakan Android Studio, dapat diberikan beberapa saran yaitu aplikasi Pembelajaran Haji dan Umroh Menggunakan Android Studio dapat dikembangkan tata caranya secara umum dengan menambahkan tata cara haji qiron dan tata cara haji ifrod yang memang ada dalam syari'at islam, mengingat di dalam aplikasi ini hanya terdapat tata cara haji tamattu'. Aplikasi Pembelajaran Haji dan Umroh Menggunakan Android Studio juga dapat ditambahkan secara online dengan menambahkan fitur-fitur seperti Login terlebih menggunakan email dahulu, sehingga pengguna dapat menyimpan datanya di dalam email pengguna. Aplikasi Pembelajaran Haji dan Umroh Menggunakan Android Studio perlu dikembangkan lagi dengan menambahkan peta lokasi online sebagai penunjuk arah. Misalnya aplikasi Google Map. Aplikasi Pembelajaran Haji dan Umroh dapat dikembangkan di sistem operasi lain semisal iOS, Windows Phone dan sebagainya. 


\section{Daftar Pustaka}

[1] Dwi Setiyawan, F. 2015. Aplikasi Pmbelajaran Tata Cara Shalat Jumat Berbasis Android, Skripsi S-1, Universitas Diponegoro, Semarang.

[2] Putra, D.P. 2014. Aplikasi Alat Bantu Manasik Haji Berbasis Android, Skripsi S-1, Universitas Muhammadiya Surakarta, Surakarta.

[3] Turban. 2002. Aplikasi Multimedia Interaktif dan Paradigma, Yogyakarta.

[4] Hukum dan Syarat Haji: https://muslim.or.id/10091-fiqih-haji-1-hukumdan-syarat-haji.html [Diakses pada tanggal 15 Agustus 2016 pukul 10.00 WIB].

[5] Manasik haji dan umroh : https://muslim.or.id/4800-tuntunan-ibadah-haji dan umroh-1.html [Diakses pada tanggal 29 Desember 2015 pukul 11.00 WIB].

[6] Abdurrahman Asy Syafi'i, A.M.. 2013. Tuntunan Manasik Haji dan Umroh. Bogor:
Pustaka Ibnu Umar.

[7] Panduan Umroh Ringkas: http://rumaysho.com/5524-panduan-umrohringkas-1.html [Diakses pada tanggal 4 Maret 2016 pukul 16.28 WIB].

[8] Lebih Mengenal Syarat-syarat Wajib Haji dan Umroh https://moslemsunnah.wordpress.com/2011/09/2 9/lebih-mengenal-syarat-syarat-wajibnya-hajidan-umrah-untaian-artikel-menggapai-hajimabrur-bag-04/ [Diakses pada tanggal 15 Agustus 2016 pukul 16.30 WIB].

[9] Salbino, S.Kom., S. Buku Pintar Gadget Android untuk Pemula. Jakarta: Kunci Komunikasi.

[10] Android Studio : http://developer.android.com/tools/studio/index. html [Diakses pada tanggal 26 Desember 2015 pukul 09.00 WIB]. 